Article

\title{
Bridging the Gap between Automated Manufacturing of Fuel Cell Components and Robotic Assembly of Fuel Cell Stacks
}

\author{
Devin Fowler ${ }^{1}$, Vladimir Gurau ${ }^{2, *}$ and Daniel Cox $^{2}$ \\ 1 GT Technologies, Tallahassee, FL 32303, USA; dfowler@gttechnologies.com \\ 2 Department of Manufacturing Engineering, Georgia Southern University, Statesboro, GA 30458, USA; \\ dcox@georgiasouthern.edu \\ * Correspondence: vgurau@georgiasouthern.edu; Tel.: +1-912-478-5205
}

Received: 15 August 2019; Accepted: 16 September 2019; Published: 20 September 2019

\begin{abstract}
Recently demonstrated robotic assembling technologies for fuel cell stacks used fuel cell components manually pre-arranged in stacks (presenters). Identifying the original orientation of fuel cell components and loading them in presenters for a subsequent automated assembly process is a difficult, repetitive work cycle which if done manually, deceives the advantages offered by either the automated fabrication technologies for fuel cell components or by the robotic assembly processes. We present for the first time a robotic technology which enables the integration of automated fabrication processes for fuel cell components with a robotic assembly process of fuel cell stacks into a fully automated fuel cell manufacturing line. This task uses a Yaskawa Motoman SDA5F dual arm robot with integrated machine vision system. The process is used to identify and grasp randomly placed, slightly asymmetric fuel cell components, to reorient them all in the same position and stack them in presenters in preparation for a subsequent robotic assembly process. The process was demonstrated as part of a larger endeavor of bringing to readiness advanced manufacturing technologies for alternative energy systems, and responds the high priority needs identified by the U.S. Department of Energy for fuel cells manufacturing research and development.
\end{abstract}

Keywords: robotic manufacturing of polymer electrolyte membrane fuel cells; robotic assembly; advanced manufacturing processes for fuel cells

\section{Introduction}

Fuel cells have the potential to replace the internal combustion engine in automotive applications and to provide power in stationary and portable power systems because they are energy-efficient, clean, and fuel-flexible [1]. Compared to other types of fuel cells, the polymer electrolyte membrane fuel cell, also known as proton exchange membrane fuel cell (PEMFC) has the advantages of delivering higher gravimetric and volumetric power density and of operating at lower temperatures, which results in a quick start up time and less wear on systems components. For these reasons, PEMFCs currently find extensive applications in transportation and stationary uses. When compared to other types of fuel cells, PEMFCs dominated the market in recent years in both number of units and in total power shipped, accounting for over $65 \%$ of global shipments in 2015. PEMFCs generated a revenue over USD 2 billion in 2015 [2] and are expected to generate USD 12 billion in 2025 [3].

A PEMFC stack consists of several single cells connected in cascade and fastened together between two end plates. A single cell consists of a membrane electrode assembly (MEA) placed between two electrically conductive bipolar plates that have flow field channels fabricated into both respective planar surfaces. An MEA consists of five components: a proton conductive membrane bounded by 
two catalyst layers, one on each side of the membrane, and two porous gas diffusion layers (GDLs) bonded each on the other side of the catalyst layers. Each single cell is equipped with two gaskets placed on the peripheral area of each flow field which are intended to prevent reactant gas leaks or leaks between electrodes.

The fuel cell stack and its components are currently being manufactured using mostly laboratory fabrication methods that have been scaled up in size, but do not incorporate high-volume manufacturing methods. A comprehensive review of current manufacturing methods for PEMFC components was published by Mehta and Cooper [4]. Overviews covering PEMFC manufacturing and manufacturing cost analysis for various applications can be found in References [5-9]. Recent progress in PEMFC design and manufacturing research has been published in References [10-38].

Manufacturing research and development is needed to prepare advanced manufacturing and assembly technologies that are necessary for low-cost, high volume fuel cell powerplant production. The U.S. Department of Energy (DOE) has identified high-priority manufacturing research and development needs for PEMFCs [39]. They include efforts to develop technologies for high-speed manufacturing of fuel cell components; to develop automated processes for assembling fuel cell stacks; to develop agile, flexible manufacturing and assembly processes; and to establish flexible automated manufacturing technology facilities.

There have been recent successful demonstrations of automated lines for PEMFC stacks assembly using general-purpose robot work-cells [40-45] and special-purpose automation lines [46,47]. In these applications, robots pick up fuel cell components such as gaskets, MEAs, and bipolar plates from presenters and place them in the fuel cell stack in a predefined order (Figure 1).

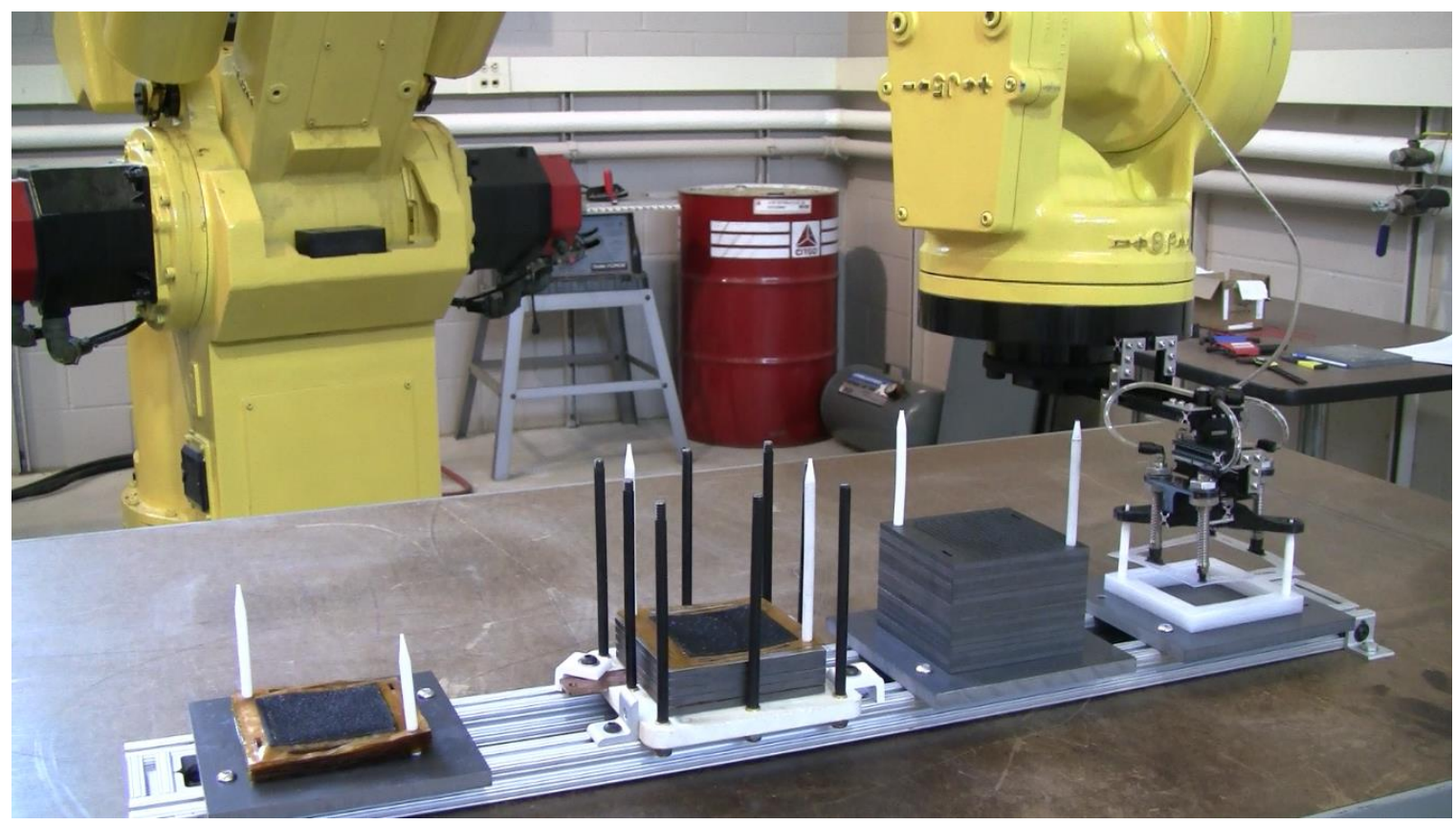

Figure 1. Fuel cell assembly line showing $50 \mathrm{~cm}^{2}$ fuel cell components that have been inserted in presenters prior to the assembly process [41]. In this image a Fanuc robot picks a gasket from the presenter to insert it in the fuel cell stack (second stack from left).

Fuel cell components are inserted in presenters before the robotic assembly process starts, all in the same orientation. In most cases fuel cell components are asymmetric, possessing a total alpha-plus-beta symmetry angle of $720^{\circ}$ according to the Design for Manufacture and Assembly (DFMA) [48] classification system for manual insertion and fastening processes. This means that the angles through which the components need to be rotated to repeat their orientation is $360^{\circ}$ around the axis of insertion, and $360^{\circ}$ around an axis perpendicular to the former. Before their insertion in 
presenters for the subsequent robotic assembly process, components need to be picked from bins where they have a random orientation. Their orientation must be examined relative to two axes of rotation simultaneously. If necessary, they must be first flipped to bring them with the correct side facing the presenter. This is equivalent to an $180^{\circ}$ rotation about axis one. If necessary, they must then be also rotated in-plane, about axis two to bring them in the correct insertion position. In particular, fuel cell gaskets and MEAs are typically only slightly asymmetric, making their orientation examination difficult. PEMFC gaskets and MEAs are also flexible, flat, thin parts which also makes their manipulation challenging. For example, the gaskets and the MEAs of a PEMFC in the range of a few $\mathrm{kW}$ may have the planar area between one hundred to a few hundred $\mathrm{cm}^{2}$ while their thickness is at submillimeter scale. This characteristic may lead to a time-consuming sorting and manipulation process. The combined effect of a fuel cell component's dimensional characteristics with that of its marginal asymmetry and with its high total alpha-plus-beta symmetry angle makes its manipulation, orientation examination, and reorientation process a repetitive work cycle that can cause mental strain and fatigue to human operators. A manual manipulation, orientation examination, and reorientation of the fuel cell components may ultimately defeat the advantages brought either by the automated manufacturing processes for fuel cell components or by the robotic assembly process.

The objective of this work was to present a robotic technology that enabled the integration of automated processes for fabrication of fuel cell components with a robotic process for assembling fuel cell stacks into a single, fully automated fuel cell manufacturing line. This process included fuel cell components pickup from a bin where they had a random orientation, handling, orientation examination, reorientation, and insertion in the presenter in preparation for a subsequent robotic assembly process. The demonstrated technology used a dual arm robot with integrated machine vision system. While this technology is applicable to any type of fuel cell components, it was demonstrated for gaskets that were designed and cut in-house for a $166 \mathrm{~cm}^{2}$ active area high temperature PEM fuel cell (HT-PEMFC) stack. Use of flexible gaskets added to the complexity of the task. The process was demonstrated at Georgia Southern University as part of a larger endeavor of bringing advanced manufacturing technologies for alternative energy systems to readiness, and respond the high priority needs identified by the U.S. Department of Energy for fuel cells manufacturing research and development [39].

\section{Materials and Methods}

The demonstration work-cell consisted of a Yaskawa Motoman SDA5F dual arm robot, in-house designed and fabricated end-effector tooling, the bin containing randomly oriented fuel cell gaskets, the presenter on which the gaskets were to be inserted all in the same orientation, the components of the Cognex In-Sight 8000 vision system, the FS100 robot controller, an air compressor, and a computer.

The presenter on which the fuel cell gaskets were stacked on consisted of a 0.25 inch thick aluminum plate with two 0.25 inch diameter poly(tetra)ethylene (PTFE) rods with one sharpened end along which the alignment holes on the fuel cell gaskets were inserted. The presenter was placed on an elevated platform made of aluminum extrusion and placed on the mounting cart in front of the robot.

Gaskets produced in an automated manufacturing line are generally collected in bins where they have a random orientation, but are aligned in a stack along one of their longer sides. In this demonstration, the bin was replaced by four corner profiles made from acrylonitrile butadiene styrene (ABS) using additive manufacturing and placed on an elevated platform between the robot and the presenter.

The Cognex In-Sight 8000 machine vision system used in this demonstration consisted of a Cognex IS8402M-373-50 camera with a C-mount manual lens having $25 \mathrm{~mm}$ focal length and 1:1.4 aperture, a CIO-Micro-CC I/O module and desktop computer with In-Sight Explorer 5.4.0 software. The camera was fixed and attached to the mobile cart through a Swivelink mounting system. 


\subsection{Fuel Cell Gaskets}

The gaskets used for this demonstration were designed and cut for a $3 \mathrm{~kW}, 165 \mathrm{~cm}^{2}$ active area HT-PEMFC stack. They were made of $0.35 \mathrm{~mm}$ thick perfluoroalkoxy (PFA) film with outside dimensions of $270 \mathrm{~mm} \times 190 \mathrm{~mm}$, an internal window cutout of $182 \mathrm{~mm} \times 102 \mathrm{~mm}$, two-7 mm diameter alignment holes and six asymmetric manifold openings. One of their corners was chamfered $5 \mathrm{~mm} \times 45^{\circ}$ to make them obviously asymmetric and enhance the machine vision process for the inspection of their orientation (Figure 2).

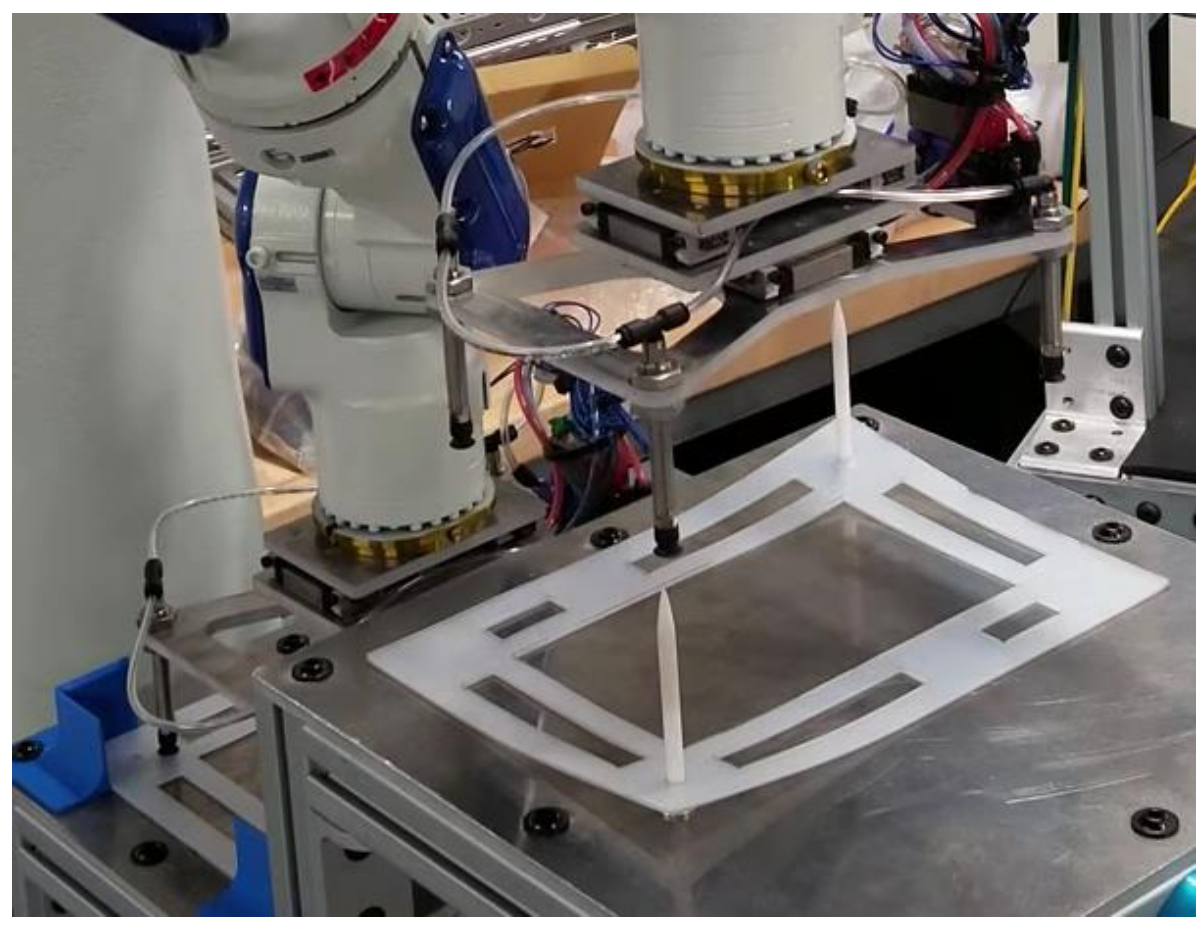

Figure 2. Fuel cell gaskets used in this research.

\subsection{Tooling}

Each robot arm was equipped with identical end-effectors designed and fabricated in house (Figure 3) based on Reference [49]. They consisted of three components cut from 0.25 inch-thick aluminum plate using a water jet. A lower aluminum plate contained four SLSA-120NR level compensators (Anver Corp.) with $10 \mathrm{~mm}$ vacuum cups and suspension mechanism for grasping the gaskets. The level compensators were used to provide a softer touch and to reduce robot indexing when picking up and releasing the gaskets from the bin and into the presenter. An upper aluminum plate was used to attach the end-effectors to the robot end-of-arm. A third, intermediate aluminum plate was connected to the upper and lower aluminum plates through two SELBZ13 miniature linear blocks and rails (Misumi USA) mounted on each side. Each rail had two water jet fabricated adjustable rigid stops which allowed the blocks to slide $3 \mathrm{~mm}$ along the rails. This system provided relative mobility in the $\mathrm{X}-\mathrm{Y}$ plane between the lower aluminum plate holding the level compensators with vacuum cups and suspension mechanism on one side, and the upper aluminum plate that connected to the robot wrist assembly on the other side. This three-plate subassembly with linear blocks and rails represented a passive compliance system with minimal friction that compensated for misalignments between the positioning holes on the fuel cell gaskets and the PTFE pins mounted on the presenter during insertion operations. This compliance system could compensate for misalignments as large as $1.5 \mathrm{~mm}$ which were much larger than the $0.06 \mathrm{~mm}$ repeatability of the Yaskawa Motoman SDA5F robot. At this time, we did not use a spring system that would re-center the end-effector. The vacuum cups 
were pneumatically connected through $4 \mathrm{~mm}$ tubing to a JV09CET miniature vacuum pump (Anver Corp.) mounted directly on the end-effectors.

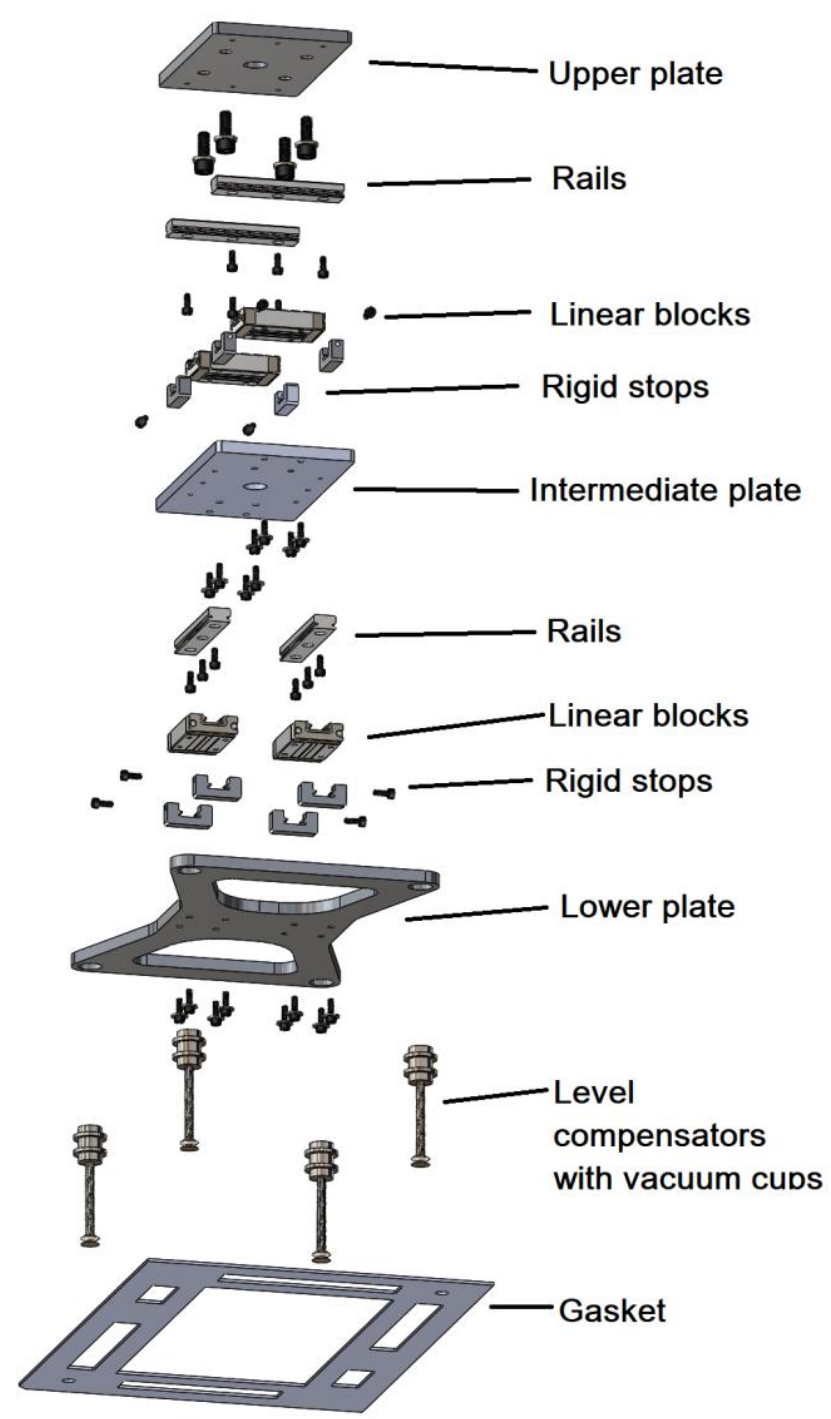

Figure 3. 3D model of the end-effector.

\subsection{Algorithm}

The robotic process consisted of a number of tasks which included fuel cell components pickup from a bin where they had a random orientation, components handling, orientation examination, reorientation, and insertion in a presenter for the subsequent robotic assembly process. This was a repetitive work cycle which iterated for a predetermined number of times equal to the number of components that needed to be inserted in the presenter. The algorithm for achieving these tasks was divided into two stages. The first stage, hereafter called the main process consisted of picking up the component from the bin, component handling, and insertion into the presenter. The second stage, the machine vision process and fuel cell component reorientation was executed for the purpose of examining the original component orientation, to take decisions regarding the procedure required for reorientation and then reorienting the components before their insertion in the presenter.

For the main process, the dual arm robot was programmed to operate in non-coordinated manipulation mode, which means that each arm performed a separate task. The flowchart for the main process is shown in Figure 4. Each arm cycle consisted of two steps. In the first step arm A picked up a fuel cell component from the bin (Figure 5a) and brought it in front of the fixed camera for image 
analysis (Figure 5b) while arm B waited for the image analysis results. This step ended at node 1 in the flowchart. In the second step, after the image analysis and fuel cell component reorientation were completed (see flowchart in Figure 6), arm A either inserted the component now having the correct orientation in the presenter while arm B simultaneously picked a new gasket from the bin (Figure $5 \mathrm{c}$ ), or, if the fuel cell component was transferred to arm $B$, waited until the latter inserted the component in the presenter. The robot then withdrew arm A while simultaneously arm B brought its fuel cell component in front of the camera. Arm A waited for the image analysis results of the component in arm B (Figure 5d). This step started at node 3 in the flow chart (Figure 4). The cycle of arm B was identical with the cycle of arm A but was out of phase one step. The controller counted the number of iterations already executed and if necessary, executed a new iteration. For the main process, the robot was programmed using the MotoSim EG-VRC simulation and off-line programming software.

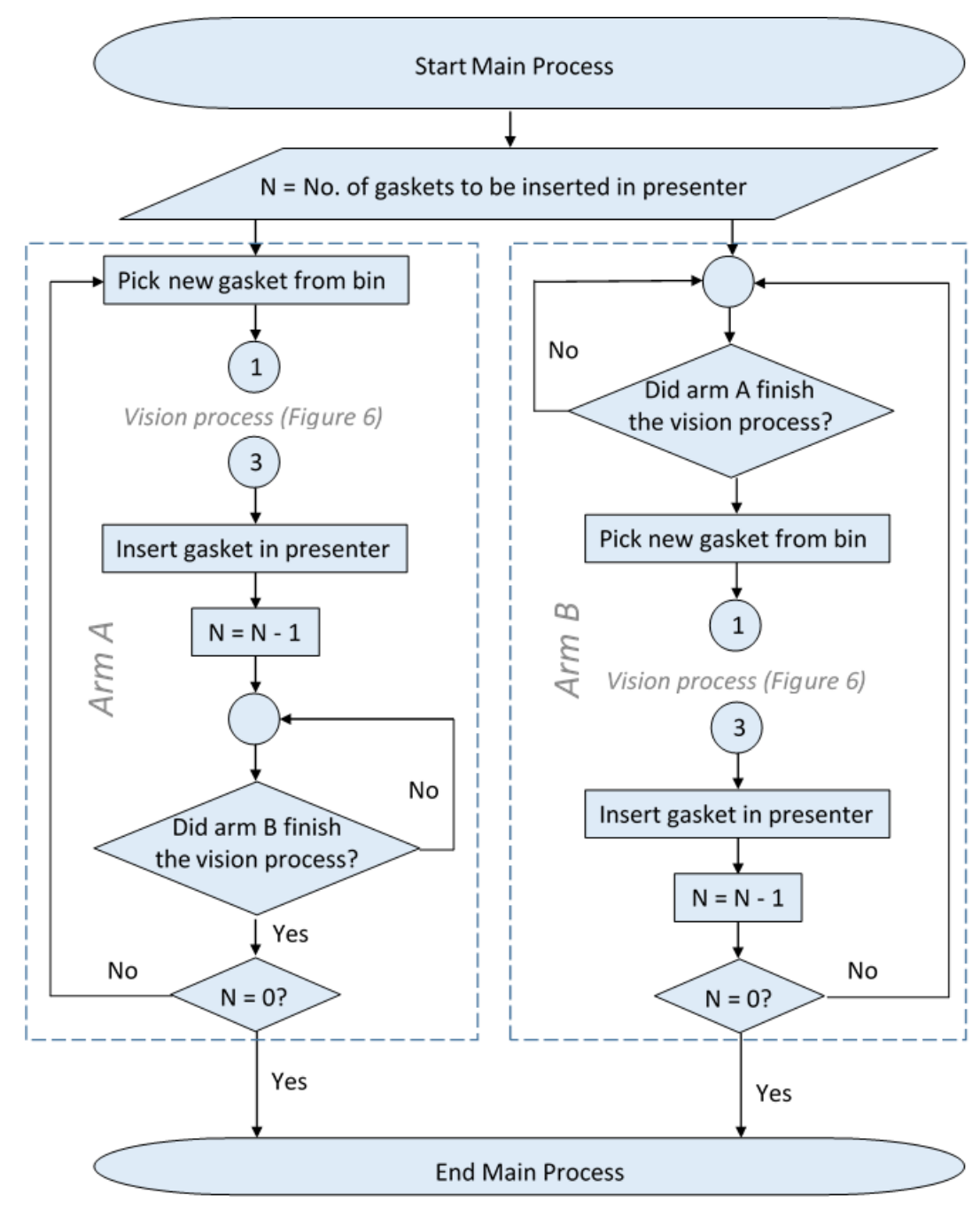

Figure 4. The flowchart of the main process.

The second stage consisted of image acquisition and analysis using the Cognex machine vision system, deciding the actions necessary to be taken to reorient the fuel cell components and then reorienting them. For this stage, the robot was programmed to operate both in non-coordinated, as well as coordinated manipulation mode. In the latter mode, both arms collaborated to accomplish the same task.

The flow chart for this process is shown in Figure 6. The fuel cell component orientation in the bin was examined relative to two axes of rotation simultaneously (see the insert of Figure 7). The component orientation was determined through image analysis by identifying the corner with 
a $5 \mathrm{~mm} \times 45^{\circ}$ chamfer. A robot arm brought the component in front of the fixed camera with the first corner in the camera's field of view. The image was acquired and compared to previously taught images. If the chamfer was identified, the inspection result was "pass" (Figure 8), otherwise "fail". If the vision system failed to identify the chamfer at the first corner, the robot arm brought the second corner in the camera's field of view and the image acquisition and analysis repeated. The process repeated until the machine vision system identified the chamfered corner. The fuel cell components in the original bin could be in one of four possible positions. The relative position of the chamfered corner provided information of the actions necessary to be taken to reorient the component (see Figure 7). When the machine vision system identified the chamfered corner ("pass"), depending on the position of this corner the robot decided the actions to be taken. It may have needed to flip the fuel cell component by transferring it from one hand to the other (Figure 9). This action is equivalent to rotating the component $180^{\circ}$ about axis one and was achieved by calling subroutine "Flip". For this task the arms operated in coordinated manipulation mode. If necessary, the fuel cell component had to be rotated in-plane, about axis two to bring it in the correct insertion position. This was achieved by rotating the end-effector $180^{\circ}$ about its end-of arm and was completed by calling subroutine "Rotate".

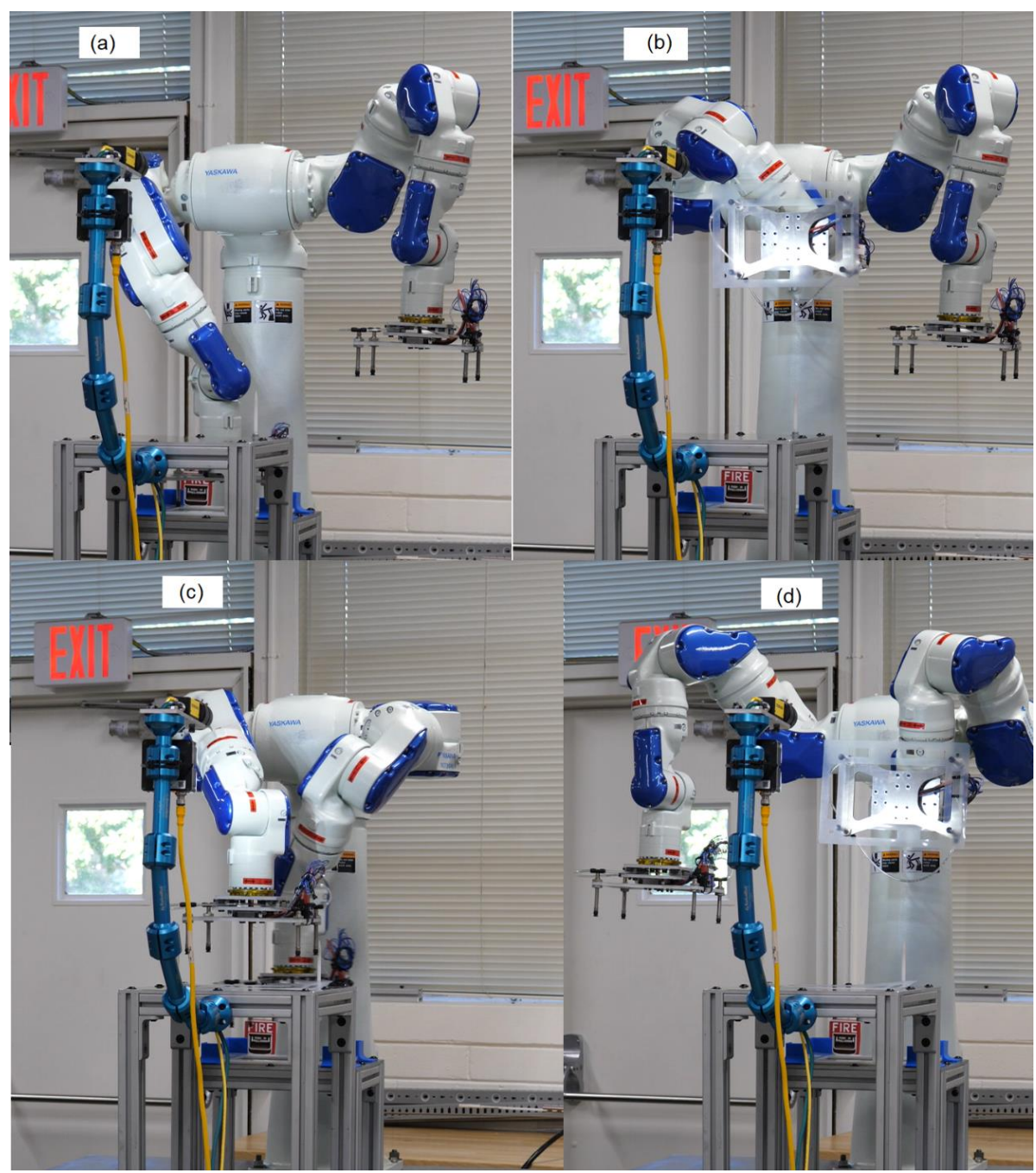

Figure 5. Fuel cell component transferring steps from bin to presenter. (a) Arm A picks a component (in this case, a gasket) from bin; (b) arm A brings the gasket in front of camera while arm B waits for image analysis results; (c) arm A inserts the gasket in the presenter while arm B picks a new gasket from the bin; (d) arm B brings the gasket in front of camera while arm A waits for image analysis results. The cycle for arm B was identical to the cycle of arm A, and out of phase one step. 


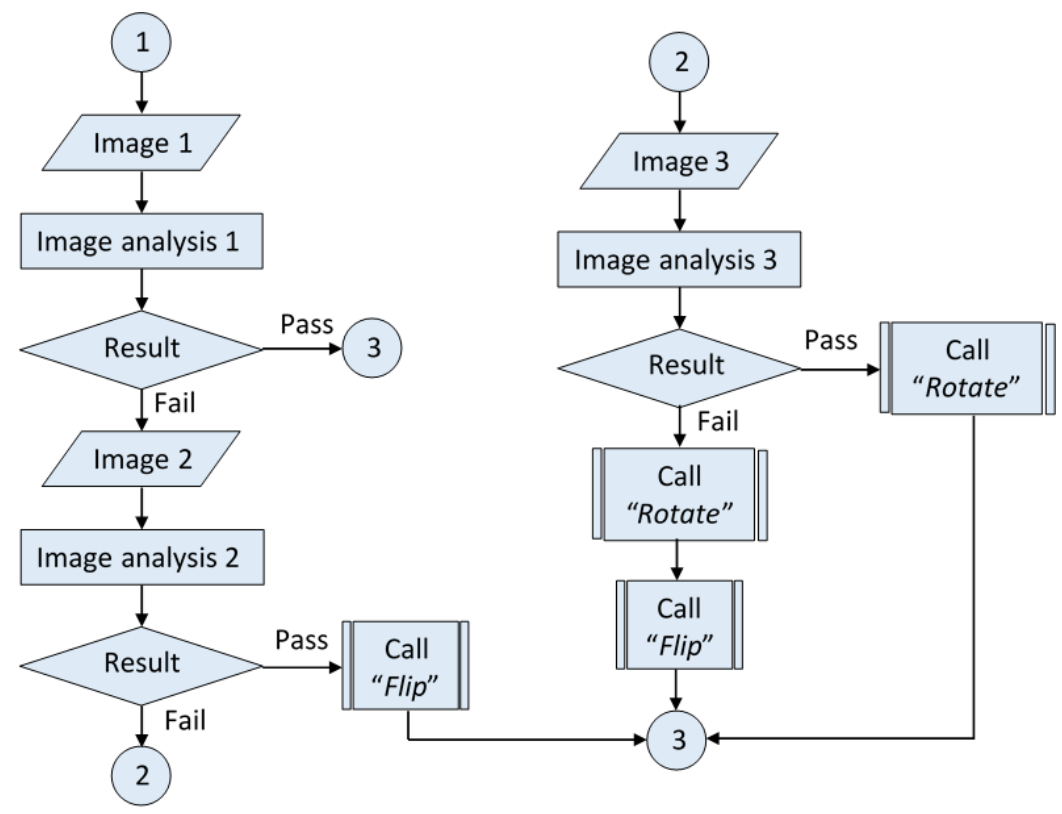

Figure 6. The flowchart for machine vision process, for taking decisions regarding the procedure required to reorient the fuel cell component and for reorienting them.

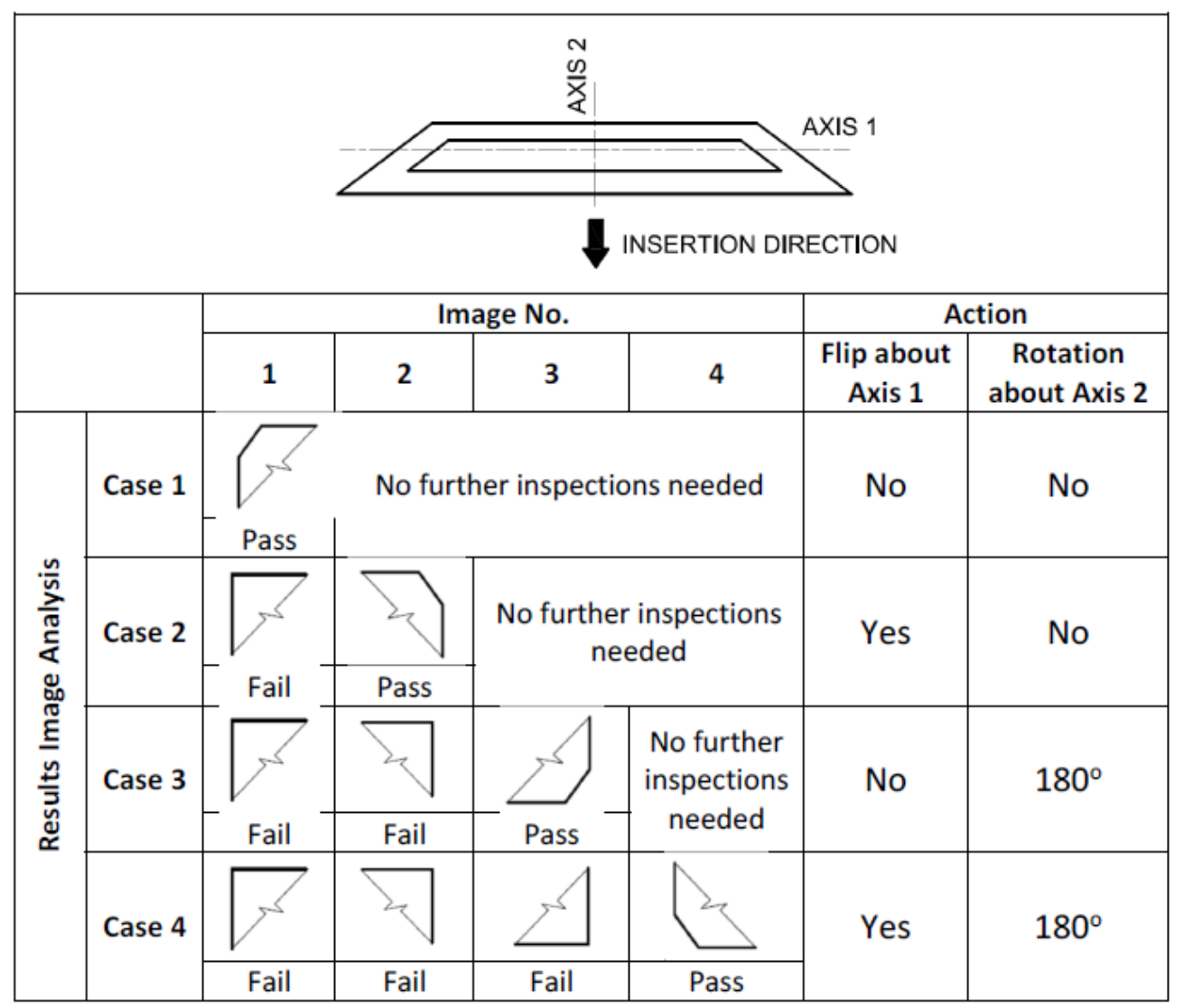

Figure 7. Machine vision process cases and the actions taken for each image analysis result. The insert shows the orientation of axes one and two relative to the insertion direction of the fuel cell component in the presenter and in fuel cell stack. Flipping the fuel cell component was achieved by passing it from one robot hand to the other. This process was equivalent to rotating the component $180^{\circ}$ about axis one. 


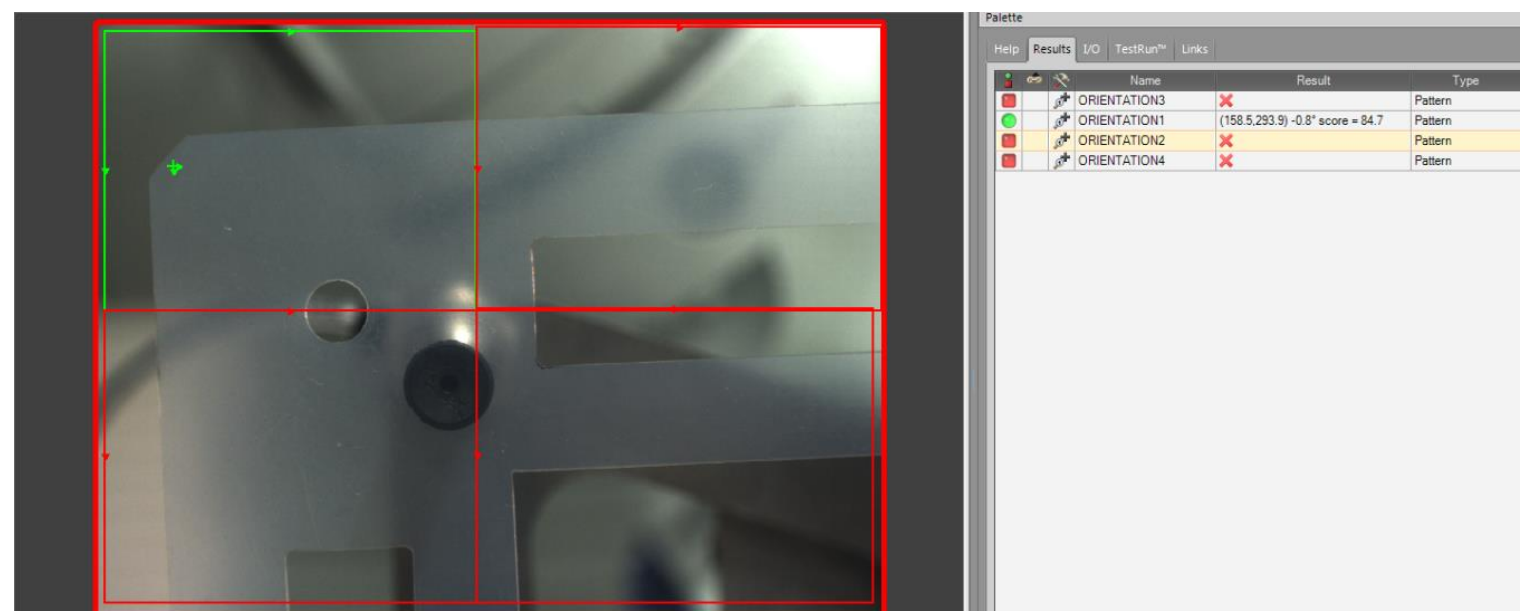

Figure 8. Image analysis result showing identification of the chamfered gasket corner in the first position.

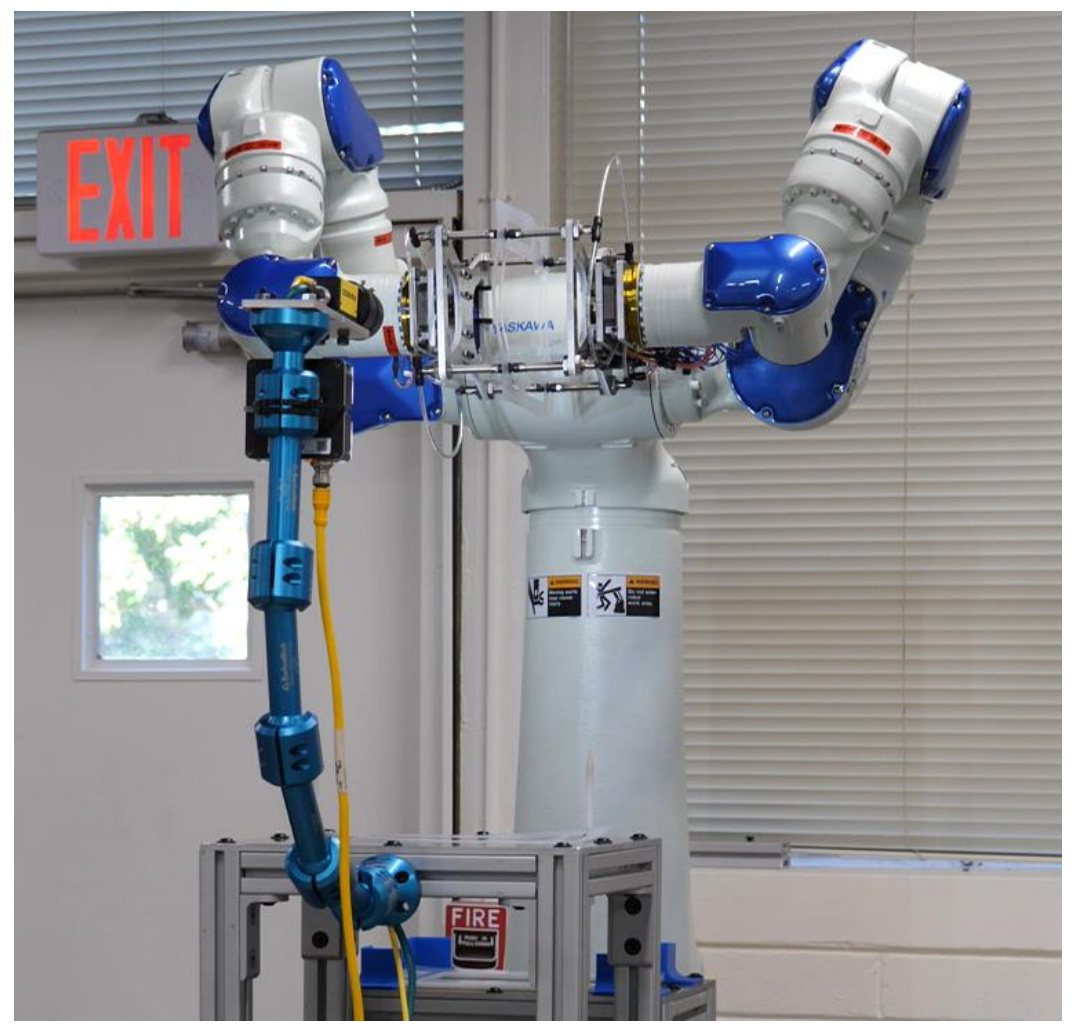

Figure 9. Robot hands operating in coordinated manipulation mode to flip the fuel cell component.

The robot program was created in INFORM III programing language and simulated using MotoSim EG VRC off-line programming software before it was loaded on the robot controller. This off-line programing software allowed for importing 3D CAD models of the tooling, fixtures, and hardware components to simulate the robot work-cell. After the program was written, it was played back in the simulator to verify its intended operation, to prevent unwanted collisions with the work-cell hardware and to optimize the path of the end-effectors (Figure 10). Once the program was verified and optimized, it was downloaded from the computer to the FS100 controller. 


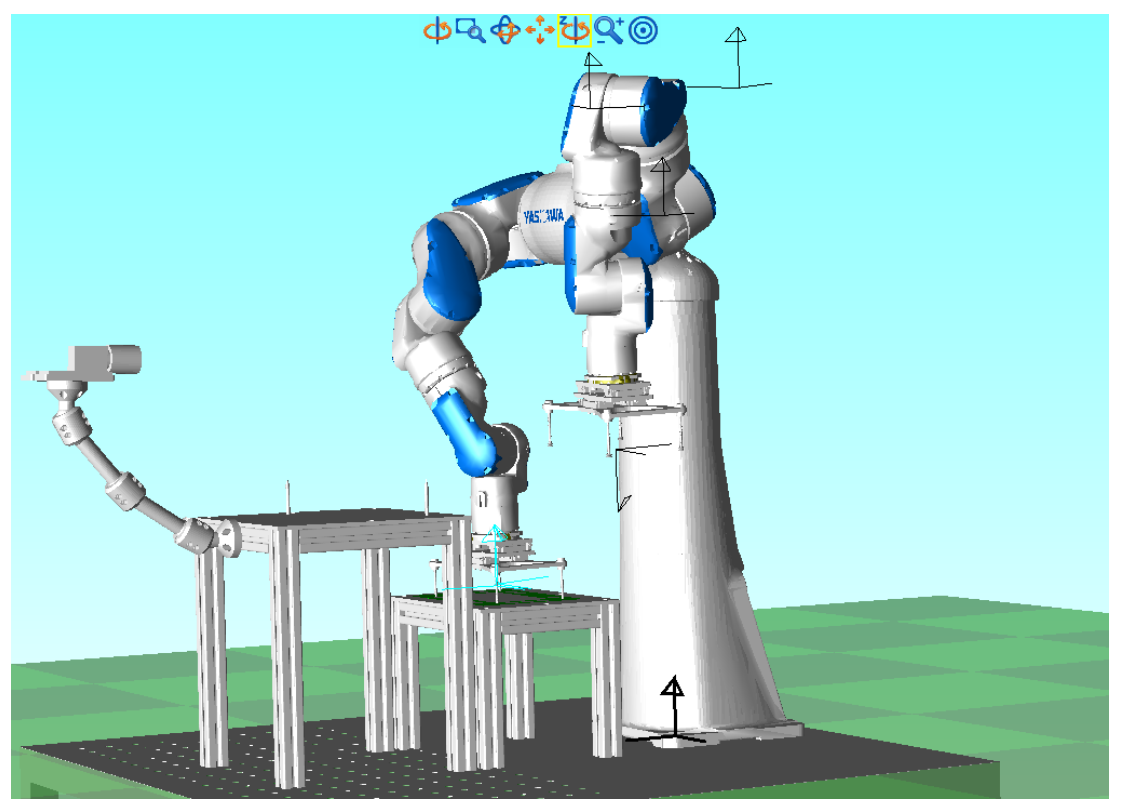

Figure 10. Work-cell and robot operation simulated with MotoSim EG VRC off-line programing software.

The machine vision program was developed with the EasyBuilder function of the In-Sight Explorer 5.4.0 software and used an Edge tool to inspect for the presence or absence of the chamfered corner of the gasket (see Figure 8) based on pre-taught images.

For a more detailed presentation of the work described here, see Reference [50]. The robot program written in INFORM III (Program S1) and a video clip demonstrating the manufacturing process (Video S1) are provided as Supplementary Materials.

\section{Results}

The time necessary to accomplish each process step is shown in Table 1. The duration of the image analysis and component reorientation depended on the original orientation of the component in the bin, which translated to the number of image analyses to be taken and the type of orientation steps that needed to be performed. Cases 2 and 4 required flipping the fuel cell component from one robot hand to the other and therefore lasted longer. Rotation of the component $180^{\circ}$ about axis two did not add extra time since it was performed while the hand withdrew from the front of the camera and prepared for the next step. Note that the last step, inserting the fuel cell component in the presenter and withdrawing the hand took place simultaneously while the other hand picked a component from the bin and brought it in front of the camera, and therefore did not add additional time to the total cycle. The chances for a fuel cell component to be in any position in the bin are equal, and therefore it was expected that for large number of components, the number of components that were in any of the four positions was the same. The average time required to transfer a gasket from the bin to the presenter was therefore equal to the sum between the time required by the first step ( $6.45 \mathrm{~s})$, and the average time required by image analysis and reorientation $(7.9 \mathrm{~s})$.

To compare the robot vs. human productivity, a group of five workers were asked to transfer 15 gaskets from the bin to the presenter as fast as they could while retaining the accuracy and without being told the reason of the experiment. Each worker performed three runs and the time necessary to finish the task and the number of misplaced gaskets in the presenter was recorded. The initial orientation of the gaskets in the bin was random in all cases. The results are shown in Table 2. For this short task all workers outperformed the robot, the averaged cycle time to transfer 1 gasket from the bin to the presenter being $5.81 \mathrm{~s}$ for human subjects, compared to $14.35 \mathrm{~s}$ for the robot. However, the robot will outperform significantly the workers over an eight hour shift due to its constant work pace and due to the fact that it does not require downtime for food and rest, and it does not suffer from fatigue. 
In one instance one human subject placed two gaskets with the wrong orientation in the bin. This demonstrates that for such dull, repetitive work cycles human error is possible even for short tasks. The workers were asked their impression of the task they performed. Typical answers include: "The experiment was annoying; it was easy to phase out and just work. I feel like muscle memory caused error". "Interesting and harsh. Caused me to push myself and was mindless like gaming". "Mindless but alright. It could get old". "Dark surfaces would make it easier for sorting". "Boring and easy".

Table 1. Duration of each operation and average cycle time for transferring one fuel cell component.

The last step did not add additional time since it was performed simultaneously with the first step.

\begin{tabular}{ccc}
\hline Operation & Time (s) & $\begin{array}{c}\text { Average Cycle Time for } \\
\text { Transferring One Gasket (s) }\end{array}$ \\
\hline Pick up gasket from the bin and bring it in front of camera & 7.45 & \multirow{2}{*}{$\begin{array}{c}\text { T. } \\
\text { Image analysis and reorientation Case 1 }\end{array}$} \\
\hline Image analysis and reorientation Case 2 & 9.35 \\
\hline Image analysis and reorientation Case 3 & 6.30 \\
\hline Image analysis and reorientation Case 4 & 13.0 \\
\hline Insert gasket in presenter and withdraw the hand & 6.30 \\
\hline
\end{tabular}

Table 2. Productivity of human subjects transferring 15 gaskets.

\begin{tabular}{ccccccc}
\hline \multirow{2}{*}{ Operator } & \multicolumn{2}{c}{ Run 1 } & \multicolumn{2}{c}{ Run 2 } & \multicolumn{2}{c}{ Run 3 } \\
\cline { 2 - 7 } & Time (m:s) & Errors & Time (m:s) & Errors & Time (m:s) & Errors \\
\hline 1 & $1: 46.88$ & 2 & $1: 43.99$ & 0 & $1: 43.76$ & 0 \\
\hline 2 & $1: 24.23$ & 0 & $1: 19.12$ & 0 & $1: 18.62$ & 0 \\
\hline 3 & $1: 39.30$ & 0 & $1: 32.12$ & 0 & $1: 25.63$ & 0 \\
\hline 4 & $1: 34.84$ & 0 & $1: 34.04$ & 0 & $1: 26.84$ & 0 \\
\hline 5 & $1: 10.27$ & 0 & $1: 08.95$ & 0 & $1: 04.96$ & 0 \\
\hline
\end{tabular}

\section{Cycle Time Optimization}

Optimization of the robot speed was not prioritized during the experiment due to inherent safety concerns in a University laboratory. The robot moves were run at relatively low speeds, but the traces of the robot end-effectors were recorded and their length were calculated using the Trace Manager function of MotoSim EG VRC software. These traces were used for the calculation of the theoretical maximum speeds and minimum cycle times. Fifteen runs were simulated for a maximum robot speed of $1500 \mathrm{~mm} / \mathrm{s}$ and for fuel cell components placed randomly in the bin in order to determine the average optimized cycle time. The cycle time of the simulated operation decreased by more than $90 \%$. We note that this represents a theoretical optimum, since it does not account for equipment limitations such as vacuum gripper systems which may release the fuel cell components at high speeds. Nevertheless, these calculations indicated that there was significant room for improvements that can lead to optimizing the cycle time.

\section{Conclusions}

We demonstrated a robotic technology for sorting, reorientation, and stacking fuel cell components in presenters in preparation for their subsequent robotic assembly in fuel cell stacks. The technology was demonstrated with fuel cell gaskets due to increased complexity challenges these components present, but it could be readily used for other fuel cell components such as MEAs and bipolar plates. The demonstrated process used a dual arm robot with integrated machine vision system. This robotic technology enabled the integration of automated manufacturing processes for fuel cell components 
with a robotic fuel cell stack assembly process that was previously demonstrated, into a fully automated fuel cell manufacturing line. The robot productivity was compared to the productivity of five workers. For a short task the robot was outperformed by the workers. It was however expected that the robot productivity would be significantly higher than that of the workers over an eight hour shift due to its constant work pace and no downtime needed for food and rest. The experiment demonstrated that for such dull, repetitive work cycles human error is possible even for short tasks. While the robotic process was demonstrated at relatively low speeds due to safety concerns in a University laboratory, simulations using the end-effector trajectories indicate that the robot cycle time can be reduced by more than $90 \%$.

Supplementary Materials: The following are available online at http://www.mdpi.com/1996-1073/12/19/3604/s1, Video S1: Demonstration of the manufacturing process. Program S1: The robot program written in INFORM III for FS100 controller used in this technology demonstration.

Author Contributions: Conceptualization, V.G.; investigation, D.F.; supervision, D.C.; writing—original draft, V.G.

Funding: This research received no external funding.

Acknowledgments: This work was made possible with funds from Georgia Southern University.

Conflicts of Interest: The authors declare no conflict of interest.

\section{References}

1. U.S. Department of Energy. Hydrogen and Fuel Cells Program. Fuel Cells. Available online: https: //www.hydrogen.energy.gov/fuel_cells.html (accessed on 4 September 2017).

2. Global Markets Insight. Fuel Cell Market Size by Application (Stationary, Portable, Transport), by Product (PEMFC, DMFC, SOFC), Industry Analysis Report, Regional Outlook (U.S, Canada, Germany, UK, Japan, South Korea, South Africa, Brazil), Application Potential, Price Trends, Competitive Market Share \& Forecast, 2016-2024. Available online: https://www.gminsights.com/industry-analysis/fuel-cell-market (accessed on 5 September 2017).

3. Grand View Research. Fuel Cell Market Analysis by Product (PEMFC, PAFC, SOFC, MCFC), By Application (Stationary, Transportation, Portable) and Segment Forecast, 2014-2025. Available online: http://www. grandviewresearch.com/industry-analysis/fuel-cell-market (accessed on 12 September 2017).

4. Mehta, V.; Cooper, J.S. Review an Analysis of PEM fuel Cell Design and Manufacturing. J. Power Sources 2003, 114, 32-53. [CrossRef]

5. Battele Memorial Institute. Manufacturing Cost Analysis of 1, 5, 10 and $25 \mathrm{~kW}$ Polymer Electrolyte Membrane (PEM) Fuel Cell Systems for Material Handling Applications; DOE Contract No. DE-EE0005250; U.S. Department of Energy: Washington, DC, USA, 2017.

6. Pratt, J.W.; Chan, S.H. Maritime Fuel Cell Generator Project; SANDIA Report, SAND2017-5751; Sandia National Lab: Livermore, CA, USA, 2017.

7. Benchmarking and Best Practices Center of Excellence. Manufacturing Fuel Cell Manhattan Project; US Gov. Contract No. N00014-08-D-0758; Benchmarking and Best Practices Center of Excellence. Available online: https://www.energy.gov/sites/prod/files/2014/03/f12/manufacturing_fuel_cell_manhattan_project.pdf (accessed on 1 August 2019).

8. Battele Memorial Institute. Manufacturing Cost Analysis of 5 and $10 \mathrm{~kW}$ Backup Power Applications; DOE Contract No. DE-EE0005250; U.S. Department of Energy: Washington, DC, USA, 2016.

9. Pratt, J.W.; Klebanoff, L.E.; Munoz-Ramos, K.; Akhil, A.A.; Curgus, D.B.; Schenkman, B.L. Proton Exchange Membrane Fuel Cells for Electrical Power Generation O-Board Commercial Airplanes; SANDIA Report, SAND2011-3119; Sandia National Lab: Livermore, CA, USA, 2011.

10. Roth, C.; Bleith, P.; Schwoebel, C.A.; Kaserer, S.; Eicher, J. Importance of Fuel Cell Tests for Stability Assessment-Suitability of Titanium Diboride as an Alternative Support Material. Energies 2014, 7, 3642-3652. [CrossRef]

11. Han, J.; Charpentier, J.F.; Tang, T. An Energy Management System of a Fuel Cell/Battery Hybrid Boat. Energies 2014, 7, 2799-2820. [CrossRef] 
12. Ma, H.; Cheng, W.; Fung, F.; Hsu, C.; Lin, C. Compact Design of 10 kW Proton Exchange Membrane Fuel Cell Stack Systems with Microcontroller Units. Energies 2014, 7, 2498-2514. [CrossRef]

13. Hwang, K.; Kim, J.H.; Kim, S.Y.; Byun, H. Preparation of Polybenzimidazole-Based Membranes and Their Potential Applications in the Fuel Cell System. Energies 2014, 7, 1721-1732. [CrossRef]

14. San Martin, I.; Ursua, A.; Sanchis, P. Modelling of PEM Fuel Cell Performance: Steady-State and Dynamic Experimental Validation. Energies 2014, 7, 670-700. [CrossRef]

15. Chang, L.Y.; Chen, H.C. Linearization and Input-Output Decoupling for Nonlinear Control of Proton Exchange Membrane Fuel Cells. Energies 2014, 7, 591-606. [CrossRef]

16. Kulikovsky, A. Polarization Curve of a Non-Uniformly Aged PEM Fuel Cell. Energies 2014, 7, 351-364. [CrossRef]

17. Liu, J.; Yuan, Y.; Bashir, S. Functionalization of Aligned Carbon Nanotubes to Enhance the Performance of Fuel Cell. Energies 2013, 6, 6476-6486. [CrossRef]

18. Chen, Y.S.; Lin, S.M.; Hong, B.S. Experimental Study on a Passive Fuel Cell/Battery Hybrid Power System. Energies 2013, 6, 6413-6422. [CrossRef]

19. Tavcar, G.; Katrasnik, T. An Innovative Hybrid 3D Analytic-Numerical Approach for System Level Modelling of PEM Fuel Cells. Energies 2013, 6, 5426-5485. [CrossRef]

20. Alink, R.; Gerteisen, D. Modeling the Liquid Water Transport in the Gas Diffusion Layer for Polymer Electrolyte Membrane Fuel Cells Using a Water Path Network. Energies 2013, 6, 4508-4530. [CrossRef]

21. Wan, Z.; Chang, H.; Shu, S.; Wang, Y.; Tang, H. A Review on Cold Start of Proton Exchange Membrane Fuel Cells. Energies 2014, 7, 3179-3203. [CrossRef]

22. Bozzini, B.; Bocchetta, P.; Gianocelli, A. Coelectrodeposition of Ternary Mn-Oxide/Polypyrrole Composites for ORR Electrocatalysts: A Study Based on Micro-X-ray Absorption Spectroscopy and X-ray Fluorescence Mapping. Energies 2015, 8, 8145-8164. [CrossRef]

23. Stassi, A.; Gatto, I.; Sacca, A.; Baglio, V.; Arico, A.S. Enhancement of Oxygen Reduction and Mitigation of Ionomer Dry-Out Using Insoluble Heteropoly Acids in Intermediate Temperature Polymer-Electrolyte Membrane Fuel Cells. Energies 2015, 8, 7805-7817. [CrossRef]

24. Jeong, S.K.; Lee, J.S.; Woo, S.H.; Seo, J.A.; Min, B.R. Characterization of Anion Exchange Membrane Containing Epoxy Ring and $\mathrm{C}-\mathrm{Cl}$ Bond Quaternized by Various Amine Groups for Application in Fuel Cells. Energies 2015, 8, 7084-7099. [CrossRef]

25. Balzarotti, R.; Latorrata, S.; Stampino, P.G.; Cristiani, C.; Dotelli, G. Development and Characterization of Non-Conventional Micro-Porous Layers for PEM Fuel Cells. Energies 2015, 8, 7070-7083. [CrossRef]

26. Kiatkittkul, P.; Nohira, T.; Hagiwara, R. Nonhumidified Fuel Cells Using N-Ethyl-N-methyl-pyrrolidinium Fluorohydrogenate Ionic Liquid-poly (Vinylidene Fluoride-Hexafluoropropylene) Composite Membranes. Energies 2015, 8, 6202-6214. [CrossRef]

27. Choi, J.S.; Sohn, J.Y.; Shin, J. A Comparative Study on EB-Radiation Deterioration of Nafion Membrane in Water and Isopropanol Solvents. Energies 2015, 8, 5370-5380. [CrossRef]

28. Vinh, N.D.; Kim, H.M. Comparison of Numerical and Experimental Studies for Flow-Field Optimization Based on Under-Rib Convection in Polymer Electrolyte Membrane Fuel Cells. Energies 2016, 9, 844. [CrossRef]

29. Endo, N.; Ogawa, Y.; Ukai, K.; Kakihana, Y.; Higa, M. DMFC Performance of Polymer Electrolyte Membranes Prepared from a Graft-Copolymer Consisting of a Polysulfone Main Chain and Styrene Sulfonic Acid Side Chains. Energies 2016, 9, 658. [CrossRef]

30. Cheng, S.; Xu, L.; Li, J.; Fang, C.; Hu, J.; Ouyang, M. Development of a PEM Fuel Cell City Bus with a Hierarchical Control System. Energies 2016, 9, 417. [CrossRef]

31. Lee, H.S.; Cho, C.W.; Seo, J.H.; Lee, M.Y. Cooling Performance Characteristics of the Stack Thermal Management System for Fuel Cell Electric Vehicles under Actual Driving Conditions. Energies 2016, 9, 320. [CrossRef]

32. Sgambetterra, M.; Brutti, S.; Allodi, V.; Mariotto, G.; Panero, S.; Navarra, M.A. Critical Filler Concentration in Sulfated Titania-Added Nafion ${ }^{\mathrm{TM}}$ Membranes for Fuel Cell Applications. Energies 2016, 9, 272. [CrossRef]

33. Jang, H.; Sutradhar, S.C.; Yoo, J.; Ha, J.; Pyo, J.; Lee, C.; Ryu, T.; Kim, W. Synthesis and Characterization of Sulfonated Poly (Phenylene) Containing a Non-Planar Structure and Dibenzoyl Groups. Energies 2016, 9, 115. [CrossRef] 
34. Wang, C.; Wang, S.; Peng, L.; Zhang, J.; Shao, Z.; Huang, J.; Sun, C.; Ouyang, M.; He, X. Recent Progress on the Key Materials and Components for Proton Exchange Membrane Fuel Cells in Vehicle Applications. Energies 2016, 9, 603. [CrossRef]

35. Qin, Y.; Wang, X.; Chen, R.; Shangguan, X. Water Transport and Removal in PEMFC Gas Flow Channel with Various Water Droplet Locations and Channel Surface Wettability. Energies 2018, 11, 880. [CrossRef]

36. Byun, S.J.; Wang, Z.H.; Son, J.; Kwak, D.K.; Kwon, Y.C. Experimental Study on Improvement of Performance by Wave Form Cathode Channels in a PEM Fuel Cell. Energies 2018, 11, 319. [CrossRef]

37. Latoratta, S.; Stampino, P.G.; Cristiani, C.; Dotelli, G. Performance Evaluation and Durability Enhancement of FEP-Based Gas Diffusion Media for PEM Fuel Cells. Energies 2017, 10, 2063. [CrossRef]

38. Mao, L.; Davies, B.; Jackson, L. Application of the Sensor Selection Approach in Polymer Electrolyte Membrane Fuel Cell Prognostics and Health Management. Energies 2017, 10, 1511. [CrossRef]

39. U.S. Department of Energy. Roadmap on Manufacturing R\&D for the Hydrogen Economy. Available online: https://www.hydrogen.energy.gov/pdfs/roadmap_manufacturing_hydrogen_economy.pdf (accessed on 4 September 2017).

40. Gurau, V.; Fowler, D.; Cox, D. Robotic Technologies for Proton Exchange Membrane Fuel Cell Assembly. In Proton Exchange Membrane Fuel Cells; Taner, T., Ed.; InTech: London, UK, 2018; pp. 21-34. ISBN 978-1-78923-066-6.

41. Gurau, V.; Armstrong-Koch, T. Further Improvements of an End-Effector for Robotic Assembly of Polymer Electrolyte Membrane Fuel Cells. Energies 2015, 8, 9452-9463. [CrossRef]

42. Williams, M.; Tignor, K.; Sigler, L.; Rajagopal, C.; Gurau, V. Robotic Arm for Automated Assembly of Proton Exchange Membrane Fuel Cell Stacks. J. Fuel Cell Sci. Technol. 2014, 11, 054501. [CrossRef]

43. Laskowski, C.M. Design-for-Manufacture Guidelines for Automated Assembly of Proton Exchange Membrane (PEM) Fuel Cell Stacks. Ph.D. Thesis, Rensselaer Polytechnic Institute, Troy, NY, USA, 2011.

44. Laskovski, C.; Derby, S. Fuel Cell ASAP: Two Iterations of an Automated Stack Assembly Process and Ramifications for Fuel Cell Design-For-Manufacture. J. Fuel Cell Sci. Technol. 2011, 8, 031004. [CrossRef]

45. KUKARobotGroup. The Production of Proton Exchange Membrane Fuel Cells with a KUKA Robot. Available online: https://www.youtube.com/watch?v=E-vcRR4mC6w (accessed on 14 September 2017).

46. Konold, P.; Muminovic, A.; Wehreim, M. Assembly of Fuel Cells and Stacks with Robots. In Research and Education in Robotics: EUROBOT 2008; Gottscheber, A., Enderle, S., Obdrzalek, D., Eds.; Springer: Berlin/Heidelberg, Germany, 2009; pp. 168-179.

47. Zentrum für BrennstoffzellenTechnik. Fuel Cell Manufacturing Plant/Automatisierte Brennstoffzellenmontage am ZBT. Available online: https://www.youtube.com/watch?v=KhrcHO_qw80 (accessed on 14 September 2017).

48. Boothroyd, G.; Dewhurst, P.; Knight, W.A. Product Design for Manufacture and Assembly, 3rd ed.; CRC Press: Boca Raton, FL, USA, 2011.

49. Gurau, V. Robotic Fuel Cell Assembly System. US Patent 2015/0158179 A1, 11 June 2015.

50. Fowler, D. Hydrogen Fuel Cell Gasket Handling and Alignment with Machine Vision Integrated Dual Arm Robot. Master's Thesis, Georgia Southern University, Statesboro, GA, USA, 2019.

(C) 2019 by the authors. Licensee MDPI, Basel, Switzerland. This article is an open access article distributed under the terms and conditions of the Creative Commons Attribution (CC BY) license (http://creativecommons.org/licenses/by/4.0/). 